\title{
INCREASING ACCESS IN ONLINE HIGHER EDUCATION
}

\author{
John Bourne, Janet C. Moore, John Sener
}

The Sloan Consortium

Frank Mayadas

The Sloan Foundation

Linda F. Ettinger

The University of Oregon

\begin{abstract}
This paper investigates how access to higher education in the United States can be increased through further integration of online education. The search for opportunities to increase access to online education examined multiple prospective higher education contexts. A series of papers produced by participants in the 2005 Sloan-C summer workshop is synthesized and presented in this overview. Individual papers are included in the publication, providing analyses of specific opportunities.
\end{abstract}

\section{KEYWORDS}

Online Learning, Access to Higher Education, Online Enrollment Growth, Scaling Online, Minorities, Seniors, Scientific Instrumentation, Industry, Retention, Community Colleges

\section{INTRODUCTION}

In 2005, a team of Sloan Consortium (Sloan-C) researchers studied growth opportunities in online higher education. The specific thrust of the study was to understand and make recommendations about how online education, using Asynchronous Learning Networks (ALNs), can grow to become a more common component in higher education, equally available as face-to-face, thus providing greater access to higher education.

Online education provides access to higher education to people who could not otherwise secure an education in the discipline of their choice. Growth in online education is an important Sloan-C goal because online education provides learners more choices in topics of study, more flexibility when and where they learn, and more affordability. People who could not secure an education via traditional means due to factors such as travel distance or time constraints now can learn online.

However, online education has not yet become one of the standard ways of providing education in many institutions of higher education. Our goal is to change this situation by expanding access to online learning in many different venues so that it provides a viable option along side face-to-face learning. Ultimately, the population of the nation can become more educated as online methods take their place alongside traditional instructional methods. Our purpose in this paper is to show where and how it is possible to grow online education. 
The goal of the Sloan Foundation's "Learning Outside the Classroom” program is to assist learning institutions to provide high quality education to all who wish to learn anywhere and at anytime. In the ten years since the Sloan Foundation started this program and the Sloan Consortium of institutions dedicated to quality online education has grown to well over 2 million learners [1]. At Sloan-C, we have observed $20 \%$ annual growth in online enrollments during the past few years. However, higher education remains inaccessible to many potential learners. For example, Department of Education statistics cite [2] that there are over 16 million learners in higher education in the U.S. today; hence, online education reaches perhaps only $15 \%$ of potential learners (i.e., those people in the population who could immediately become learners if provided access to learning. An estimate of the total number of addressable learners is about $1 / 3$ of the total population of the U.S.). In addition, there are many potential learners from the ranks of the remaining population (about 200M remaining) who could learn if given the opportunity.

Despite the successes of online learning options in higher education, a number of obstacles still impede the dream of "anytime, anyplace" learning for motivated individuals. Most apparent today is the fact that the full breadth of academic disciplines is not available. In addition, many institutions currently offering online education have not been able to scale their ALN programs to meet the demand. Moreover, the average citizen does not know where to go to find a credible online program.

In this study we take a hard look at the goal to further integrate the use of online learning in higher education as a way to increase access. There is a need for institutions to meet the anticipated demand for access to quality online learning opportunities while at the same time, promote a broad awareness of ALN among the citizenry. We believe that informed citizens will be better able to select high-quality ALN programs from the growing number of alternatives.

\section{MAPPING THE TERRITORY FOR INCREASED ACCESS}

\section{A. The Scope of Online Higher Education}

Figure 1 presents a concept map showing the areas of interest of this investigation. The focus is on Higher Education. The map documents key areas that supply students to higher education, ranging from K-12 populations to off-shore learners. While this map can certainly be expanded, it provides a sense of the scope of interests under consideration in this particular study. 
Figure 1: A Concept Map of the Territory for Increased Access in Higher Education

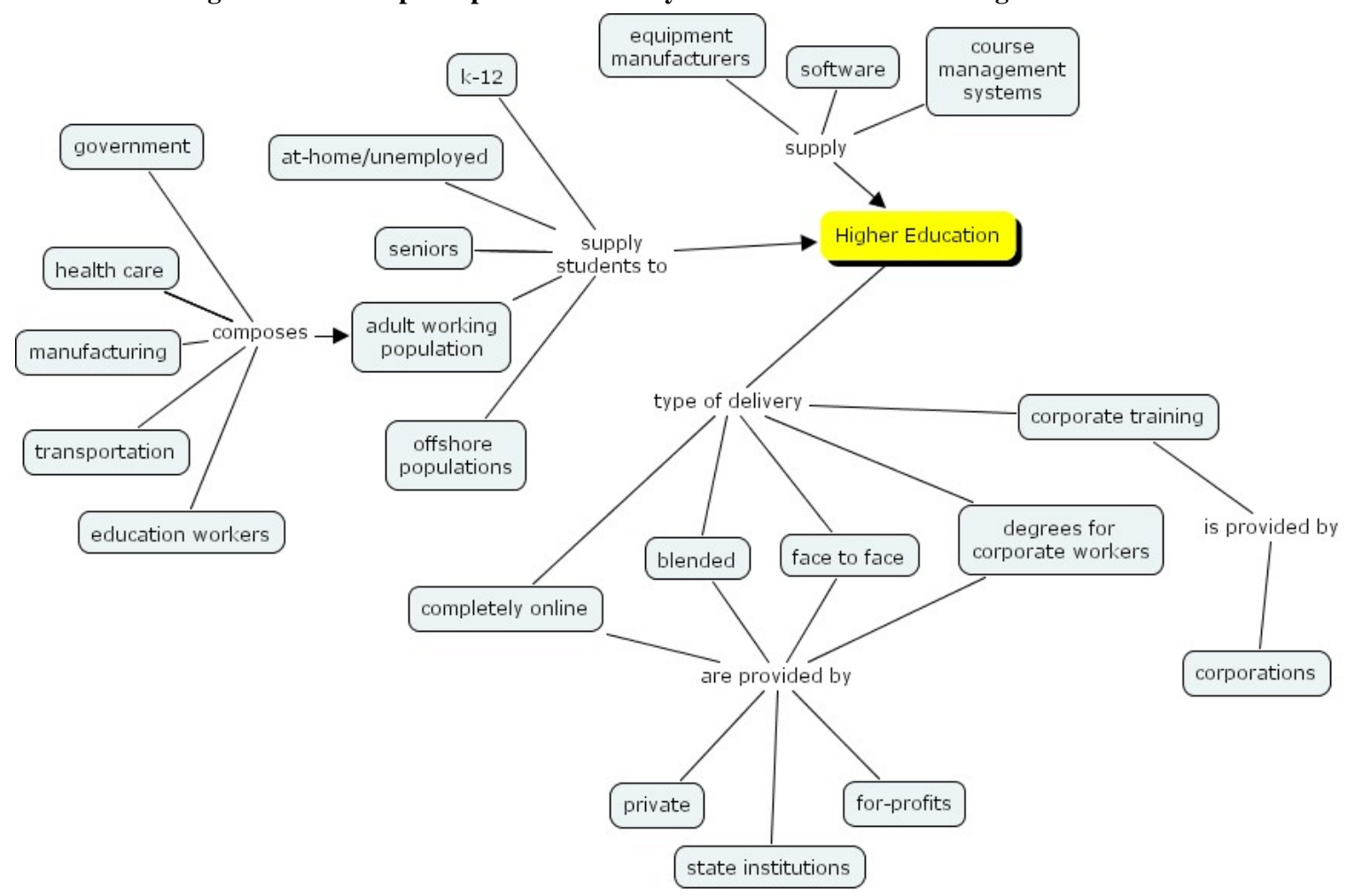

Each of the areas in this map represents an opportunity for increased access to higher education through online learning. For example, suppliers of technology (equipment, software, course management systems) can affect the rate of growth through supplying innovations that make it easier to access higher education. Similarly, a supply chain of learners who are already accustomed to online learning (e.g. high school students) will drive the numbers demanding access to online higher education.

\section{B. How Many Potential Learners are there for Online Education?}

\begin{tabular}{|l|}
\hline Population in U.S. $=$ over 296,000,000 \\
Population in world $=6.5$ Billion \\
\hline
\end{tabular}

The population of the U.S. is nearly 300 million, or about $5 \%$ of the world's population of 6.5 billion people. In the U.S., some 90 million people are engaged in some type of education (about one third of the population, including $\mathrm{K}-12$, higher education and adult learning). If the rest of the world eventually mirrors the same fraction of learners as in the U.S., this would mean that about two billion people would be continuously learning.

Of the total of nearly 90 million learners in the U.S., we estimate that only two to three million utilize a completely online modality. Higher education has the largest number of learners online, with about 2.8 million students who have taken at least one online course. Secondary education reports around 1 to 2 million and corporations report close to 20 million [3]. As a starting point, our goal is to explore what can be done in the U.S. to provide a 10-fold increase in online enrollments within the higher education community over the next ten years. 
A Sloan-C survey in 2004 yielded information from chief academic officers that there were about 2.8 million people taking one or more online courses in institutions of higher education in 2004 [1]. The number of total enrollments is likely to be less than twice this number. The National Center for Education Statistics (NCES) estimates [4] that between 2000 and 2013, total enrollment is projected to increase to 18.2 million (low estimate: 17.7 million, high estimate: 18.8 million). Hence, the only way to reach this goal would be to greatly expand the learner pool and convert everyone to online education-an unrealistic option. If blended learning is included as part of the goal, it may be possible to reach, although it is still probably unlikely.

New sources of supply may come forward to fill the pool-growth in online learners is quite high in the for-profit institutions as are learners in government organizations such as eArmyU. For example, a report about the Illinois Virtual Campus (Fall 2004) indicates that most growth in Illinois online learners comes from the for-profits [9]. The Chronicle of Higher Education [5] notes that for-profits now serve only 2.4\% of the market but that about $40 \%$ of the total income in 2004 generated by online higher education was in the for-profit sector. Growth rates in the for-profits may dramatically accelerate in the upcoming years. Consider Figure 2 (from the College Board and UBS reports $[3,6]$ ) that shows that most learners in the U.S. are in the $\mathrm{K}-12$ segment $[6,7,8]$. College and professional education learners number from 16 to 18 million, and potential and reachable corporate adult learners have been estimated at 17 million [3].

Figure 2: Populations of Learners in Different Segments (Estimated in Millions) from College Board and UBS Reports, 2004

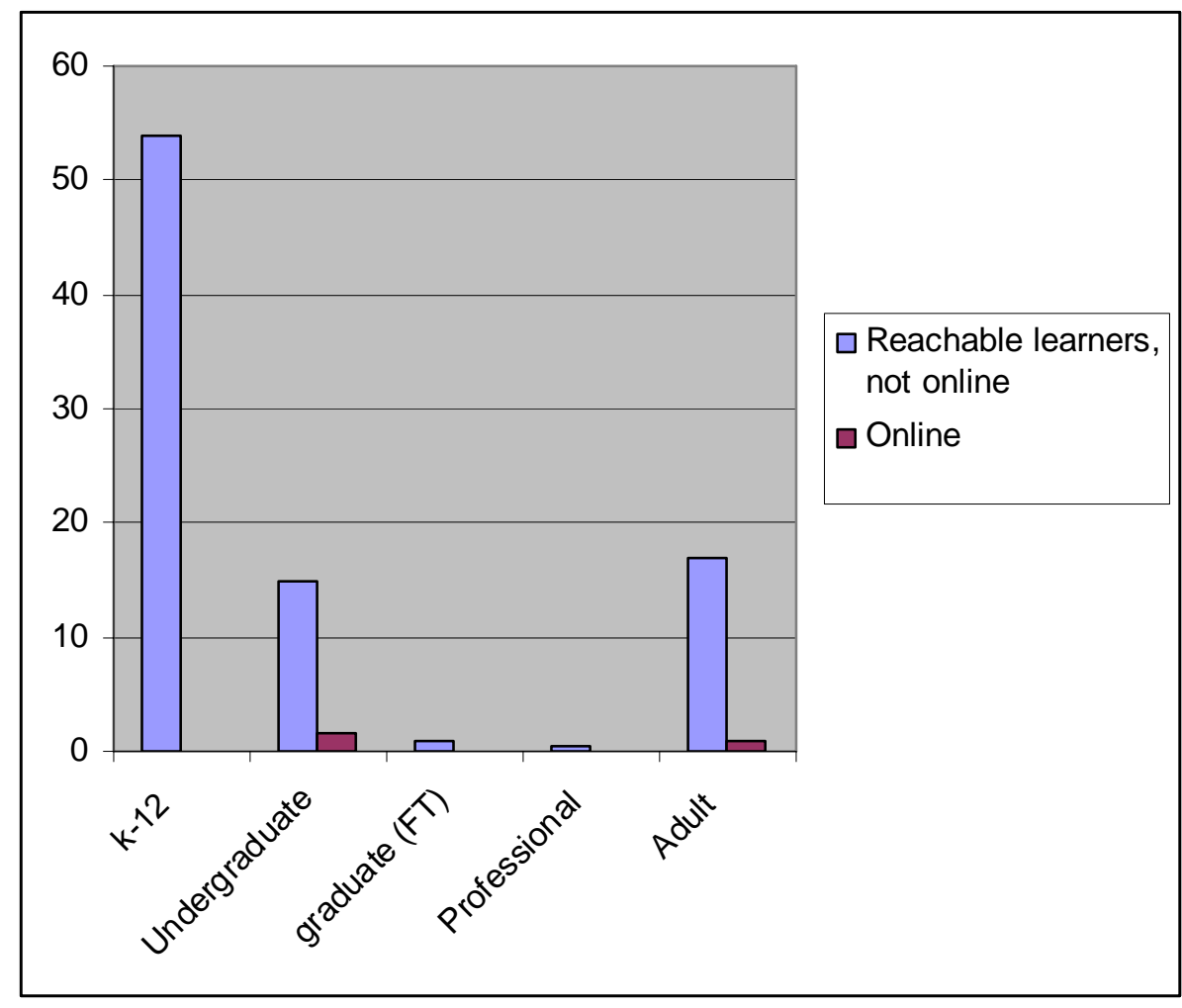

Figure 2 clearly demonstrates that most learners are not now online. Further, the graduate and professional segments of learners in higher education contain many fewer potential online learners when compared to the undergraduate population. 
To understand where opportunities exist to employ online learning, we can begin to identify areas in which online learning is underutilized. Figure 3 presents an estimate of potential reachable online learners in different education segments. By identifying where the need is for online education, it may be possible to direct the impact of the introduction of online methods. An examination of Figure 3 leads to the following projections:

- In higher education, online learning, including use of blended methods, can reach the most potential learners in near term (16-18M).

- In corporations, perhaps only $25 \%$ of the total population is reachable (20M) (from the United Business Services (UBS) report of the number of people estimated to be working in the corporate world [3]).

- In $\mathrm{K}-12$, the total learner population could be affected, but we are less optimistic due to uncertainties in how online methods would be funded and implemented. Countering our cautious estimate, the Pew Internet and Family Life Project estimates that almost $90 \%$ of teens between 12 and 17 are currently online [10]. Pressure from this student group may cause our estimate to be low. For now, we estimate that 40 million students (about $2 / 3$ of a population grown to 60M) could eventually become online learners (in this estimate, we include blended populations of learners). In the near term, the number of online students in K-12 is likely to be much lower.

- In government and health care, we predict about 50\% could ultimately employ online education (20M).

- In the remainder of the population (subtracting about 25 million children under 6 [10], a smaller percentage of interest in online education is projected. If we reduce the total U.S. population of 290 million by (a) higher education (20/20M), (b) K-12 (40/55M), (c) corporate (20/80M), (d) government and health care (21/42 M), and (e) children (25 M), about additional 100 million people potentially remain untouched by formal online education. If about $20 \%$ of those utilized online education in some way (e.g., continual training, help) then the total reachable population could be on the order of 120 million $(20+40+20+21+20)$.

Thus, a very rough estimate of the total reachable population for online education is about 100-120 million. For a current online U.S. learning population of nearly 2.5 million [1] to reach 100 million at a component annual growth rate (CAGR) of 20\%, would require over 20 years. Assuming a CAGR of $40 \%$, this level could be achieved in under 12 years. 
Figure 3: Potential Online Learners in Different Segments of the Population (Millions)

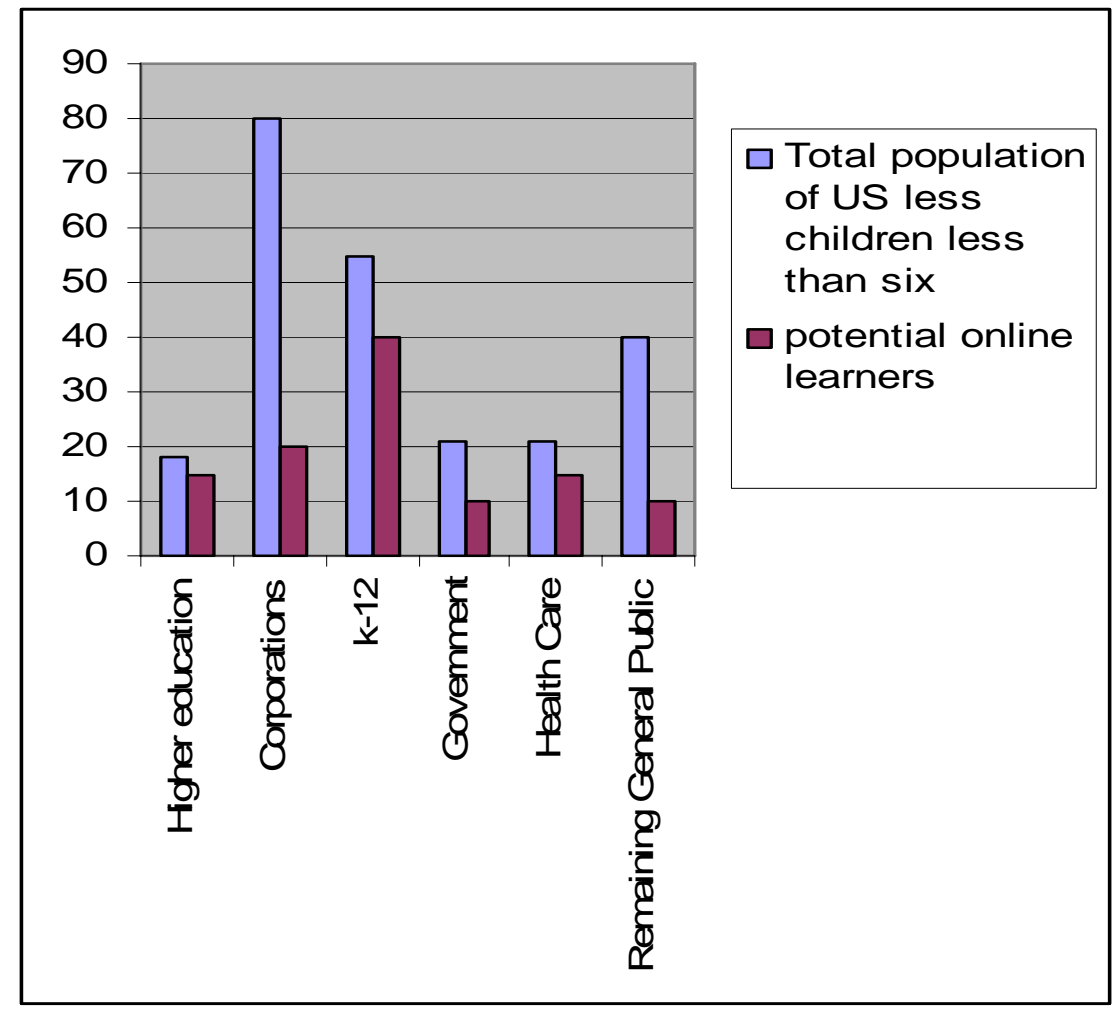

Extending online learning offshore yields astonishing numbers. If the number of potential learners in the U.S. is on the order of $40 \%$ of the U.S. population (120M (addressable learners)/300 (total population)), and the world population is 20 times larger than the U.S. (6B/.3B), then there is a huge potential number of learners in the world. Even if the percentage of addressable learners outside the U.S. is half of the U.S. addressable learner percentage ( $20 \%$ rather than $40 \%$ ), there would still be over a billion addressable learners in the world!

\section{Traditional Higher Education (16M: Addressable: 12-16M)}

Higher education program types are described in terms of learner populations that include:

- Undergraduates

o Traditional students

o Offshore populations

o High school, remedial populations

- Graduate and Professional Education

- Continuing Education

o Adult students

o Corporate training

o Lifelong learners 
The learners listed above are enrolled in the following types of public and private institutions [7]:

\begin{tabular}{lr} 
Control of Institution & Enrollment \\
\cline { 2 - 2 } Public & $12,158,811$ \\
Private, nonprofit & $3,181,806$ \\
Private, for-profit & 444,780 \\
Total & $15,785,397$
\end{tabular}

Other authoritative sources provide slightly different estimates. For example, The Chronicle of Higher Education estimates total college enrollment at 16,679,000 in 2005 [11].

The above breakout clearly shows that most of the opportunity for expansion lies in the public sector. Table 1 shows additional breakout by Carnegie Classification [7]. In each category, we estimate the potential reachable numbers of learners. Our estimates of percent reachable were made by examining the amount of current interest in online utilization at different types of institutions and then projecting forward accordingly.

Table 1: Enrollment by Carnegie Classification and Estimate of Reachable Learners

\begin{tabular}{|l|c|c|}
\hline \multicolumn{1}{|c|}{ Carnegie Classification } & Enrollment & $\begin{array}{c}\text { Number of Estimated Reachable } \\
\text { Learners Using Online or } \\
\text { Hybrid Education }\end{array}$ \\
\hline Doctoral/Research Universities-Extensive & $3,218,033$ & $1.5 \mathrm{M}(\sim 50 \%)$ \\
\hline Doctoral/Research Universities-Intensive & $1,150,652$ & $.6 \mathrm{M}$ \\
\hline Masters Colleges and Universities I & $3,068,843$ & $2 \mathrm{M}(\sim 65 \%)$ \\
\hline Masters Colleges and Universities II & 300,251 & $.2 \mathrm{M}$ \\
\hline Baccalaureate Colleges-Liberal Arts & 378,203 & $.2 \mathrm{M}$ \\
\hline Baccalaureate Colleges-General & 529,291 & $.2 \mathrm{M}(\sim 40 \%)$ \\
\hline Baccalaureate-Associates Colleges & 123,098 & .05 \\
\hline Associates Colleges & $\mathbf{6 , 2 9 4 , 0 5 2}$ & .005 \\
\hline $\begin{array}{l}\text { Specialized-Theological seminaries and } \\
\text { other specialized }\end{array}$ & 103,846 & .003 \\
\hline $\begin{array}{l}\text { Specialized-Medical schools and medical } \\
\text { centers }\end{array}$ & 60,465 & .002 \\
\hline $\begin{array}{l}\text { Specialized-Other separate health } \\
\text { profession schools }\end{array}$ & 43,230 & .02 \\
\hline Specialized-Other specialized institutions & 402,143 & .0000 \\
\hline Tribal colleges and universities & 15,247 & .0000 \\
\hline Carnegie missing & 98,043 & $\mathbf{4 0}$ million \\
\hline Total & $15,785,397$ & \\
\hline
\end{tabular}


The class of schools that appears to have the most potential for increasing online learning is "Associates Colleges" (with over 6 million total students and the possibility to increase enrollment through online methods). Note that these estimates are "low" in order to show what may be possible in the relatively short term (5 to 10 years). Ultimately, we believe most higher education learners will utilize online methods.

\section{IDENTIFYING OPPORTUNITIES FOR INCREASED ACCESS}

\section{A. Defining Metrics}

A listing of potential areas in which online learning can provide increased access to higher education is found below. To measure the potential numbers that each area might supply to online education, we have rated each area by:

- Total population

- Identifying the total number of potential learners

- Listing possibilities for use of online education in each area, including numbers of potential learners as a fraction of the total

- Reachability

Example growth analysis for higher education:

- $\quad$ The core of higher education

o Total learners in 10 years: $18 \mathrm{M}$ learners

o Growth from current (2004) 2.8 $\mathrm{M}$ to total higher education possibility of $18 \mathrm{M}$ would require a growth rate of $21 \%$ over the next decade. Current grow rates averaging $21 \%$ [1] would need to be maintained to reach the goal of 18 million learners in a decade.

0 If we assume reachability of the higher education population as $80 \%$, then the compound growth rate from 2.8 to $80 \% * 18=14.4$ would be reduced to $18 \%$.

- Education supplied by higher education

o To corporate entities

o To government entities

o To others, including life-long-learners and $\mathrm{K}-12$

\section{B. Analyzing the Market Segments}

The potential numbers of new online learners in higher education will vary, depending on whether discussion centers on "pure" asynchronous learning or a "blended" approach. Recent growth rates in pure ALN (defined as $80 \%$ or more online) have been around $20 \%$ per annum [1]. Of the about $16 \mathrm{M}$ learners in higher education, we expect that numbers of purely online students will ultimately be perhaps $1 / 4$ to $1 / 3$ of the total learner population. If this estimate turns out to be close, then we will reach perhaps 4 to 5 million learners at near-steady state. After that point, growth is likely to occur at the overall higher education growth rate. To reach a target of 4 to 5 million, at a growth rate of $20 \%$, will require only about 4 years. By then, (2010), we predict that most of the U.S. and Canada will have access to higher education via online; increases in the number of learners will come through making learners aware of learning opportunities and will not be inhibited because of access restrictions. 
In order to grow, institutions may wish to specialize in areas in which they have specific expertise or in populations which are particular accessible, for example, populations in a local area. Predictably, competition will drive online students to institutions where the value proposition is highest (lowest cost, most knowledge, highest prestige).

\section{Inject Blending into Traditional Higher Education}

The total number of learners that use online methods can be dramatically increased by making blended learning a routine part of higher education. If blending can be successfully implemented, then the total U.S. higher education population can be captured:

Total "pure” ALN learners $\quad 4 \mathrm{M}$

Total blended learners $\quad 15 \mathrm{M}$

Total face-to-face only $1 \mathrm{M}$

The total learning population in higher education would be $20 \mathrm{M}$ in this model. The rationale for the higher number of learners is the growth in untapped populations.

\section{Retention of Students in Traditional Higher Education by Use of Blending}

Carol Twigg has presented information [12] that indicates that one can dramatically increase the retention rate of students by introducing blended educational strategies. The data presented show the following increases in retention when blending was introduced:

- University of Alabama - $60 \%$ to $40 \%$

- Drexel University - 51\% to 38\%

- Tallahassee Community College $-46 \%$ to $25 \%$

- Rio Community College $-41 \%$ to $32 \%$

- Indiana University-Purdue University Indianapolis - 39\% to $25 \%$

- University of New Mexico - 39\% to 23\%

- University of Southern Maine - $28 \%$ to $19 \%$

- University of Iowa - $25 \%$ to $13 \%$

- Pennsylvania State University - $12 \%$ to $9.8 \%$

If the data above is correct, then a 10 to $15 \%$ increase in annual retention would add about 280,000 or more in the online segment of the learning population.

\section{Professional Societies}

There are over 4000 scholarly societies in the world [13]. The largest have hundreds of thousands of members (e.g. IEEE [14]) and the smallest, only a handful of members. If there were an average of 2000 members per society, this would represent some 6 million people. Members of professional societies take continuing education courses; many courses could be offered online in partnership with higher education institutions. The utilization of online education through professional societies also impacts the numbers of possible learners coming from the corporate sector. 


\section{Military, Government}

The military is staffed by about 1.4 million [15] soldiers and government employees that number: 12 million local, 6 million state, and 3 million federal. The creation of eArmyU [16] showed that over 40,000 soldiers could be enrolled in higher education online within a short time frame, with the potential for many more. Application of programs similar to eArmyU to the other services and to government employees in general would generate significant increases.

\section{Health Care}

Statistics from the U.S. Department of Labor, Bureau of Labor Statistics [17] find that somewhat over 12 million workers populate the U.S. health care industry; this number may be closer to $15 \mathrm{M}$, depending on the year and on whether one counts government health care employees. Health care is well-suited to online and blended techniques for education due to the dramatically time-shifted world of health professionals.

\section{Minority Colleges}

There are about .35 million enrollments in 118 Historically Black Colleges and Universities (HBCUs) [18] and about total 3.5 million minority enrollments in all higher education institutions [19]. Online and hybrid education provide a way for HBCUs and other minorities to reach more people that wish to retain their special identities.

\section{Corporate E-learning}

Interaction between the corporate work and universities might engage $20 \%$ of the total corporate population (or $10 \%$ of $20 \mathrm{M}=2 \mathrm{M}$ ). This estimate [3] could well be very different depending on interaction with other populations such as professional organizations.

\section{Senior Population}

The senior population (referred to as the "Silver Tsunami" [20] will be near 38 million in 2010 [15]. This population will be seeking education and re-education as they engage in second careers and in the necessity of earning a living in retirement. As a large population that will be computer literate, engaged and long-living, one cannot accurately predict how this group will react to online education.

\section{Increased Numbers of High School Students Attending College}

The Census bureau in 2005 indicates that $80 \%$ of the adult population are high school graduates or better, and $24 \%$ have a BS or more. Therefore, about 56\% were ready for, but did not or could not take advantage of, higher education. The Census Bureau reports that only about $35 \%$ of high school graduates enroll in college each year, and 12\% drop out [15]. If we assume a $5 \%$ increase in higher education production to move BS degrees in the population from $24 \%$ to near $30 \%$, there would be an additional annual number of perhaps 250,000 students (including reduced dropouts) at the beginning of the higher education supply chain each year that would need to receive higher education (5\% of $3 \mathrm{M}$ high school graduates).

\section{General Population}

If $5 \%$ of the general population (estimated at 40 to $70 \mathrm{M}$-see Figure 3) took online courses from higher education institutions - this increase would result in an additional 2M or 3M learners. 
No matter how you interpret the data from various government sources, the number of people that could utilize online higher education is huge.

\section{ANALYSIS OF THE OPPORTUNITIES}

Figure 4 indicates where potential exists for integrating online learning in higher education. This map shows activities that have high and moderate potential. The evolution of traditional higher education to incorporate blended learning methods has high potential, as do connections with the corporate and government worlds. Other segments have higher populations of potential learners (e.g., the Silvers) but there may be less need for education, and therefore less growth, in the upcoming years. Other possibilities exist, such as U.S. higher education serving offshore populations. Whether large numbers of non-U.S. learners might become engaged in U.S. online higher education remains to be seen. Most likely economic barriers will prevent significant growth in this area.

Figure 4: Where are Opportunities for Growth?

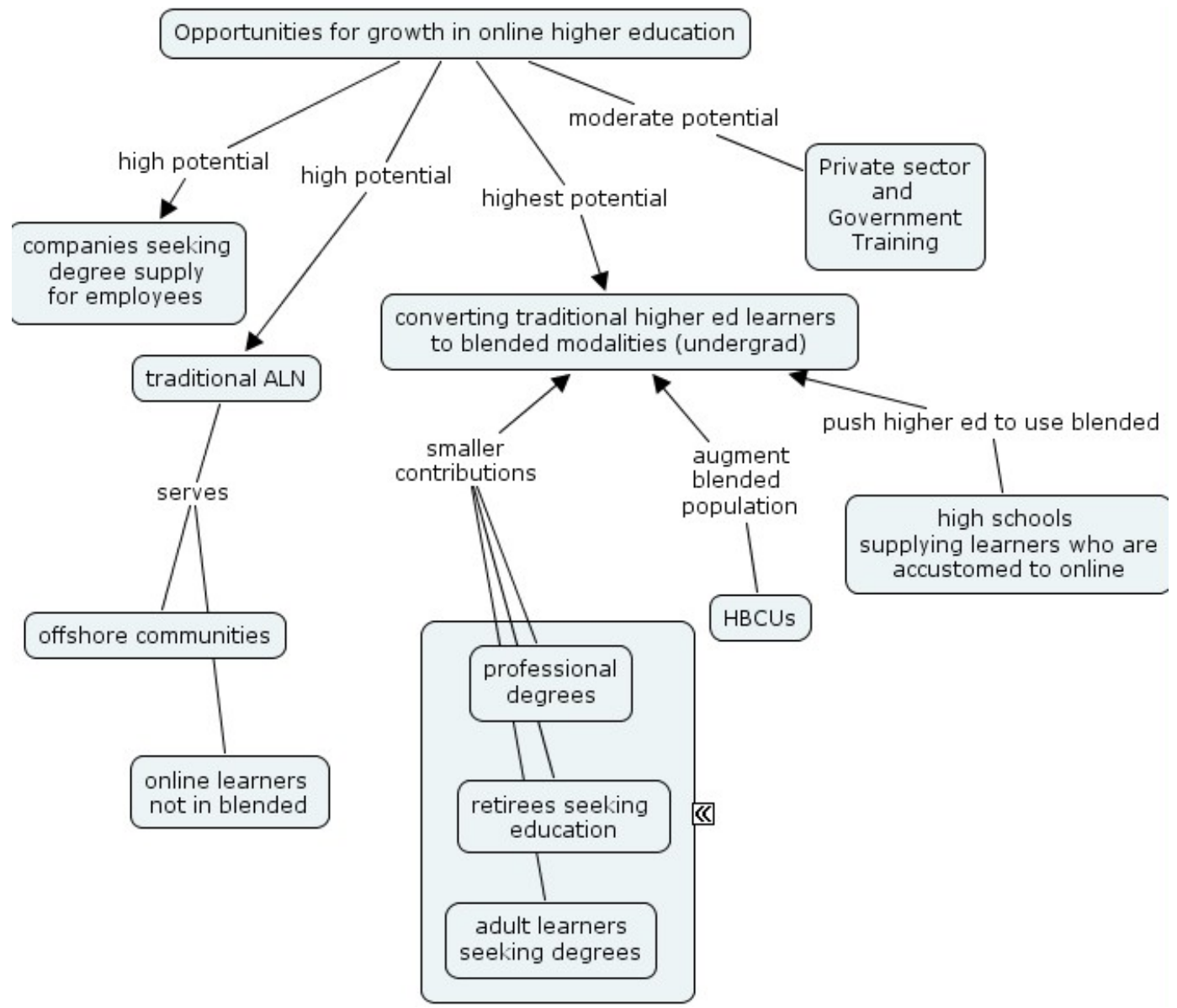

Table 2 estimates growth potential between 2006 and 2016. The potential exists for learners utilizing online methods to grow to 65 million by 2016. However, growth across many sectors of the economy is needed to reach this level. Since the higher education population is predicted to grow only to about 18 or 19 million in 10 years, learners in other sectors must be brought online in order reach 60 or 70 million. In the table, some possibilities for growth are outlined in different sectors. We suggest that most of higher education will become online-learning-enabled. Of the 20M corporate learners that are thought to be 
addressable, we estimate that about $1 / 3$ could learn online. Growth from government, health care, $\mathrm{K}-12$, seniors and the overall population is predicted as well to make up the numbers needed to reach 65 million. The values provided in this table are speculative; however, we have tried to make reasonable estimates about what might be possible. Our methodology was to estimate the population in multiple super-sectors of the economy and estimate how many of each group could ultimately be potential learners. We estimated how many are actually learning in 2006 and how many might be by 2016. Note our estimate in 2016 does not reach the number of potential learners.

Table 2: Industry Sector Analysis of 10-year Growth Potential for Online Learning-In Millions

\begin{tabular}{|c|c|c|c|c|c|}
\hline & & $\begin{array}{l}\text { Total } \\
\text { Population }\end{array}$ & $\begin{array}{l}\text { Potential } \\
\text { Online Learners }\end{array}$ & $\begin{array}{l}\text { Total Online } \\
\text { Learners }\end{array}$ & \\
\hline & & & & 2006 & 2016 \\
\hline Higher Educ & ation & & & & \\
\hline & Blended & 1 & 12 & 1 & 14 \\
\hline & ALN & 2.5 & 4 & 2.5 & 5 \\
\hline & F-2-f Only & 13 & & & \\
\hline & Students Dropping Out & -.5 & & -.2 & -0.1 \\
\hline & $\begin{array}{l}\text { Total Learning Higher Ed } \\
\text { Population }\end{array}$ & 15.5 & & 2.4 & 18.9 \\
\hline Corporate & & 80 & 20 & & \\
\hline & $\begin{array}{l}\text { Degree Acquisition From } \\
\text { Higher Education }\end{array}$ & & & 0.05 & \\
\hline & $\begin{array}{l}\text { Workshops/Continuing } \\
\text { Education }\end{array}$ & & & 1 & 15 \\
\hline Government & Military & 1.4 & & 0.3 & 0.7 \\
\hline & $\begin{array}{l}\text { Local, } \\
\text { Regional, } \\
\text { National }\end{array}$ & 22 & & 0.1 & 2 \\
\hline Health Care & & 14 & 7 & 1 & 3.5 \\
\hline $\mathrm{K}-12$ & & 55 & 25 & 0.5 & 5 \\
\hline Seniors & & 35 & 15 & 0.1 & 10 \\
\hline Remaining Pc & opulation & 73.1 & 2 & 0.1 & 5 \\
\hline Total & & 296 & 85 & 3.15 & 43.2 \\
\hline
\end{tabular}

Where should efforts to increase access to online higher education be concentrated? Participants in the Summer 2005 Sloan-C Workshop examined seven areas in-depth, as shown in Table 3. Abstracts and full papers are included in this publication. 
Table 3: Topics Investigated by Sloan-C Challenge Team Authors

\begin{tabular}{|l|l|}
\hline Topic Area & Author \\
\hline Online access in higher education & $\begin{array}{l}\text { Burks Oakley and Jacqueline Moloney } \\
\text { University of Illinois and University of } \\
\text { Massachusetts }\end{array}$ \\
\hline Online access in K-12 & $\begin{array}{l}\text { Melody Thompson } \\
\text { Pennsylvania State University }\end{array}$ \\
\hline Serving the “Silver Tsunami” & $\begin{array}{l}\text { Linda Ettinger } \\
\text { University of Oregon }\end{array}$ \\
\hline Online Access in Historically Black Institutions & $\begin{array}{l}\text { William Booth } \\
\text { Hampton University }\end{array}$ \\
\hline Getting Better: ALN and Student Success & $\begin{array}{l}\text { Janet Moore, John Sener and Marie Fetzner } \\
\text { Sloan-C and Montgomery College }\end{array}$ \\
\hline Online Access in Community Colleges & $\begin{array}{l}\text { Kathleen Ives } \\
\text { Sloan-C }\end{array}$ \\
\hline $\begin{array}{l}\text { Blended Learning: Implications for Growth and } \\
\text { Access }\end{array}$ & $\begin{array}{l}\text { Anthony G. Picciano } \\
\text { Hunter College }\end{array}$ \\
\hline
\end{tabular}

As part of this volume, the series of papers produced for the Sloan-C summer 2005 Workshop are included. Each paper presents data and describes potential improvements in access. Highlights from each paper are briefly summarized below.

\section{A. Scaling Online Education: Increasing Access to Higher Education- Jacqueline Moloney and Burks Oakley, University of Illinois and University of Massachusetts}

The authors study several institutions which have successfully scaled their online learning programs. They note a need for: (1) institutional support for online programs; (2) specialized units to facilitate support; (3) financial models to encourage scaling; (4) complete degrees; (5) interaction-based pedagogy; (6) marketing; (7) faculty training in online methods; (8) student support services that treats students as customers; (9) the ability to increase the number of faculty proportional to demand; and (10) a history of successfully serving off-campus students [21].

\section{B. Online K-12 Education: Opportunities for Collaboration with Higher- Education-Melody Thompson, Pennsylvania State University}

Thompson postulates that the traditional K-12 education system in the U.S. will become a K-16 system. Access to higher education can be increased through connecting $\mathrm{K}-12$ with higher education using multiple methods including: AP courses, college-level courses for high school students, professional development for practicing teachers and training of potential K-12 instructors. Key is to increase the flow of information about online opportunities in higher education for people engaged in K-12 education [22]. 


\section{Reaching Asynchronous Learners within the Silver Tsunami-Linda Ettinger, University of Oregon}

Ettinger explores the potential of use of ALN with baby boomers, seniors and retired citizens (collectively called the "silver tsunami"). The projection is that there will be 35 million people in the U.S. in the 55-64 age bracket by 2010. Many will seek education-both credit and non-credit. Key is attention to issues of connectivity and universal design. Partnering between institutions of higher education and other organizations that serve this group is suggested as an initial strategy to build online learning access with the Silver Tsunami [20].

\section{Insuring the Nation's Destiny: Reducing the Digital Divide-William Booth, Hampton University}

Booth examines the current role of online learning within HBCUs (Historically Black Colleges and Universities). HBCUs are identified, and progress in online education is presented. The fundamental finding is that connectivity remains a significant issue-with most students in HBCU colleges not connected, even though very significant investments in infrastructure have been made in some cases [18].

\section{E. Getting Better: ALN and Student Success-Janet C. Moore, John Sener and Marie Fetzner, Sloan-C and Montgomery College}

The authors identify a significant problem-only $18 \%$ of ninth graders ultimately obtain a higher education degree. The paper is devoted to a discussion of how use of ALNs can improve this low degree completion rate. Of special interest is a series of vignettes from colleges that have achieved a high success rate [23].

\section{F. Community Colleges and Distance Learning: Opportunities and Challenges-Kathleen Ives, Sloan-C}

Ives reviews the landscape for community colleges and recommends partnerships among larger higher education institutions, high schools and businesses. She identifies the online learning needs of the digital generation, suggests outsourcing curriculum development and proposes methods for increasing enrollment [24].

\section{G. Blended Learning: Implications for Growth and Access-Anthony G. Picciano, Hunter College}

Starting from two vignettes about how blended learning can be used in different settings, Picciano provides multiple definitions for blended learning. He examines how blending could increase enrollments in colleges and how blending would be of use in improving pedagogical processes [25].

\section{SLOAN-C RECOMMENDATIONS FOR ACTION}

The work of Sloan-C in creating the increased use of online education in America can be achieved though a variety of activities, including publications, conferences, workshops and initiatives. Our goal in this paper is to provide broad dissemination of the opportunities we have identified for expanding access to higher education through online learning. Our plan now is to focus on a set of recommendations for action that will enable ALN to become a permanent and viable component of higher education in America. 
The data and discussion in the papers summarized above serve as the basis for recommendations to achieve the objective of providing online education to those who cannot currently secure education. Specific actions must be undertaken in the following areas:

- Blended Learning. Blended learning methods must be better understood. Ongoing research documenting the best ways to implement and organize blended learning is needed, both at the course level and among institutions.

- Leadership. Higher administration in colleges and universities must understand how to best position and utilize online education for their institutions.

- Instrumentation. The effective use of online laboratories and scientific instrumentation needs to be well understood and integrated with other online and traditional pedagogies.

- Corporate Education. Continued investigation of the connections and knowledge sharing between higher education and corporate education utilizing online learning is recommended.

- Faculty Training. A wide variety of options for faculty training are needed as a way to educate faculty about pure ALN and blended online education solutions.

- Student Success. Methods of improving student success (i.e. improving retention) through use of online learning should be investigated, including research and collection of effective practices.

- Lifelong Learning. Lifelong learning is a large and diverse segment for growth of online education. Building partnerships between professional societies and existing higher education lifelong learning programs may serve as a starting point.

- Minority Engagement. Students and faculty in minority colleges can greatly benefit from use of online education. Initiatives should be undertaken that provide minority colleges ways to utilize existing infrastructure to improve access, pedagogy and faculty and student satisfaction, while also decreasing cost.

- K-12. A study is needed of how $\mathrm{K}-12$ can become more easily linked to higher education, perhaps through such vehicles as advanced placement online. Ways to productively weave blended learning into $\mathrm{K}-12$ venues should be examined.

\section{ACKNOWLEDGEMENTS}

The generous support of the Alfred P. Sloan Foundation permitted the creation of planning activities and the holding of the seventh annual summer workshop in Victoria, BC. Special thanks are given to A. Frank Mayadas, Program Officer of the Sloan Foundation, President of Sloan-C and participant in this Challenge activity, for funding of the workshop.

\section{REFERENCES}

1. Allen, I. E. \& J. Seaman. Entering the Mainstream: The Quality and Extent of Online Education in the United States, 2003 and 2004. Needham, MA: Sloan-C, 2004. http://www.sloan-c.org /resources/survey04a.asp.

2. http://nces.ed.gov//programs/projections/ch_2.asp\#2.

3. Flynn, K. A., B. Carlson and A. Fones. UBS Online Education Sourcebook. United Business Services, March 2, 2004. http://www.ubs.com/investmentresearch.

4. U.S. Dept. of Education, NCES. "Fall Enrollment Survey," various years; and Enrollment in Degree-Granting Institutions Model (See reference table 10 (http://nces.ed.gov/programs /projections/tables/table_10.asp)). Integrated Postsecondary Education Data System (IPEDS). http://nces.ed.gov/ipeds/. 
5. Blumenstyk, G. For-Profit Education: Online Courses Fuel Growth. The Chronicle of Higher Education, Outlook, 2005. http://chronicle.com/prm/weekly/v51/i18/18a01101.htm (subscription required).

6. http://www.collegeboard.com/highered/res/hel/hel.html\#grads.

7. Integrated Postsecondary Education Data System. National Center for Educational Statistics, http://nces.ed.gov/ipeds.

8. Setzer, J. C. and L. Lewis. Distance education courses for public elementary and secondary school students: 2002-2003, (NCES 2-5-010). U.S. Department of Education. Washington, DC: National Center for Education Statistics, 2005. Available online at http://nces.ed.gov/pubsearch /pubsinfo.asp?pubid=2005010.

9. http://www.ivc.illinois.edu/pubs/enrollment/Fall_04.html.

10. Lenhart, A, M. Madden and P. Hitlin. "Teens and technology: Youth and leading the transition to a fully wired and mobile nation." Reports: Family, Friends and Community, Pew Internet \& American Life Projects, 2005. http://chronicle.com/prm/weekly/v51/i18/18a01101.htm (subscription required).

11. http://chronicle.com/prm/weekly/almanac/2004/nation/0101801.htm (subscription required).

12. Twigg, C. Keynote Address. 2004 Distance Learning Conference: Madison, Wisconsin, 2004.

13. http://www.scholarly-societies.org.

14. http://www.ieee.org.

15. http://www.census.gov.

16. Stoskopf, L. D. Front and center. Sloan-C View 3(3): April, 2004. http://www.sloan-c.org /publications/view/v3n3/coverv3n3.htm.

17. U.S. Department of Labor. Bureau of Labor Statistics. http://www.bls.gov.

18. Booth, W. Insuring the nation's destiny: Reducing the Digital Divide. Journal of Asynchronous Learning Networks 10(3): July 2006, in this issue. http://www.sloan-c.org/publications/jaln /v10n3/v10n3 5booth member.asp (login required).

19. http://nces.ed.gov/programs/digest/d97/d97t209.asp, 1995.

20. Ettinger, L. Reaching asynchronous learners within the Silver Tsunami. Journal of Asynchronous Learning Networks 10(3): July 2006, in this issue. http://www.sloan-c.org/publications/jaln /v10n3/v10n3_4ettinger_member.asp (login required).

21. Moloney, J. and B. Oakley II. Scaling online education: Increasing access to higher education. Journal of Asynchronous Learning Networks 10(3): July 2006, in this issue. http://www.sloan-c.org /publications/jaln/v10n3/v10n3_2moloney_member.asp (login required).

22. Thompson, M. Online K-12 education: Opportunities for collaboration with higher-education. Journal of Asynchronous Learning Networks 10(3): July 2006, in this issue. http://www.sloan-c.org /publications/jaln/v10n3/v10n3_3thompson_member.asp (login required).

23. Moore, J. C., J. Sener and M. Fetzner. Getting better: ALN and student success. Journal of Asynchronous Learning Networks 10(3): July 2006, in this issue. http://www.sloan-c.org /publications/jaln/v10n3/v10n3 6moore member.asp (login required).

24. Ives, K. Community colleges and distance learning: Opportunities and challenges. Journal of Asynchronous Learning Networks 10(3): July 2006, in this issue. http://www.sloan-c.org /publications/jaln/v10n3/v10n3_7ives_member.asp (login required).

25. Picciano, A. G. Blended learning: Implications for growth and access. Journal of Asynchronous Learning Networks 10(3): July 2006, in this issue. http://www.sloan-c.org/publications/jaln /v10n3/v10n3_8picciano_member.asp (login required). 